\title{
Carcass characteristics and body components of Santa Inês lambs in feedlot fed on different levels of forage cactus meal ${ }^{1}$
}

\section{José Rômulo Soares dos Santos², Marcílio Fontes Cezar², Wandrick Hauss de Sousa ${ }^{3}$, Maria das Graças Gomes Cunha ${ }^{3}$, José Morais Pereira Filho², Dannylo Oliveira de Sousa ${ }^{4}$}

\author{
1 Projeto financiado pela FINEP. \\ 2 Unidade Acadêmica de Medicina Veterinária - UFCG. \\ ${ }^{3}$ Empresa Estadual de Pesquisa Agropecuária da Paraíba (EMEPA-PB). \\ ${ }^{4}$ Departamento de Nutrição e Produção Animal - FMVZ -USP.
}

\begin{abstract}
The objective of this study was to evaluate the effect of the replacement of a ground corn diet by a forage cactus meal diet on the carcass characteristics and body components of Santa Inês lambs finished in feedlot. This study was carried out at Estação Experimental de Pendência, belonging to Empresa de Pesquisa Agropecuária da Paraíba S.A. (EMEPA-PB). Forty Santa Inês male lambs in feedlot were used in the experiment. Treatments were randomly assigned to the animals according to a completely randomized design, with four treatments, which consisted of growing replacement levels of ground corn by forage cactus meal: 0, 33, 66 and 100\% of substitution and ten replications (lambs). Animals were slaughtered, and the following characteristics were evaluated: body weight, empty body weight, hot carcass weight, cold carcass weight, non-carcass components (NCC), hot carcass yield, cold carcass yield, biological yield, revenue of non components of carcass, revenues of non-carcass components, relative weight and relative value of the commercial cuts, viscera and organs' yield. Averages were submitted to analysis of variance and regression analyses at a 5\% level of probability. The replacement levels of ground corn by forage cactus meal had no influence on biological yield, revenue of the non components of carcass, relative weight and relative value of the prime and choice cuts or on the relative weight of viscera and organs. The replacement of ground corn by forage cactus meal, on the ration given to Santa Ines lambs in feedlot does not impact the biological yield, relative weight and relative value of prime and choice cuts or the relative weight of viscera and other organs.
\end{abstract}

Key Words: feeding, organs, relative weight, viscera, wholesale cuts

\section{Introduction}

With the purpose of obtaining the best quality carcasses with maximum yield, the slaughter of lambs at a live weight of $35 \mathrm{~kg}$ has been recommended, which induces feedlot finishing and the use of concentrate in the feed. One possible way to reduce the production cost consists of the use of alternative energy sources. (Melo et al., 2003).

The forage cactus meal is a cactus plant considered a vital forage plant in the semiarid region, particularly in the period of rain shortage (Muller et al., 1994), because of its characteristics similar to those of an energy concentrate, such as higher percentage of propionate in the rumen, high level of soluble carbohydrates and high digestibility of dry matter (Ben Salem et al., 1996; Lopes, 2007; Wanderley et al., 2002). Besides, forage cactus meal provides a better pattern of fermentation due to the lower percentage of starch and the higher level of pectin, compared with corn (Van Soest, 1994; Batista et al., 2003; Bispo et al., 2007). However, ruminants should not be fed only this diet because of its laxative effect, high water content and low fiber content, which cannot meet the dietary needs of these animals (Ben Salem et al., 2005; Wanderley et al., 2002). Forage cactus meal can be fed to the animals, having the following advantages: it is easy to store and transfer and provides a balanced diet. Veras et al. (2005) demonstrated the potential of forage cactus meal to feed ruminants assessing only the performance characteristics of the animals, However, in commercialization, the percentage of carcass and non-carcass components are also considered (Alves et al., 2003).

Therefore, the objective of the present study was to assess the effects of the replacement of ground corn by forage cactus meal on the characteristics of the carcass and on non-carcass components of Santa Inês lambs in feedlot.

\section{Material and Methods}

The experimental study was conducted at Estação Experimental de Pendência, which belongs to EMEPA (Empresa de Pesquisa Agropecuária da Paraíba S.A), located in the city of Soledade, Paraiba, in the micro-region 
of the western Curimataú, in the Agreste Meso-Region of Paraíba, in the semi-arid region. The station is located at coordinates latitude S $7^{\circ} 8^{\prime} 18^{\prime \prime}$, longitude W $36^{\circ} 27^{\prime} 2^{\prime \prime}$ and altitude of 534 meters.

Forty 90-day-old Santa Inês lambs, with a 15.52-kg average live weight were distributed in four groups, each one fed on one of the diets prepared with $0,33,66$ or $100 \%$ forage cactus meal in the concentrate in replacement of ground corn (Table 1 ). The dry matter used in the experiment was tifton hay. The giant cultivar of forage cactus was obtained after dehydration of spineless cactus produced at EMEPA. The forage cactus was chopped and dried in sunlight for three days, and then ground. The metabolizable energy values of the diet were calculated considering $1 \mathrm{~kg}$ of total digestible nutrients (NDT) equal to $4.409 \mathrm{Mcal}$ of digestible energy (DE), to $0.82 \mathrm{Mcal}$ of ME (Coelho da Silva \& Leão, 1979).

Animals were identified and randomly distributed in individual cages $(1.10 \times 0.55 \mathrm{~m})$, with troughs and drinking vessels. They were dewormed, and adaptation was performed in 14 days.

Diet was offered twice a day (50\% in the morning and $50 \%$ in the afternoon) and in an amount that ensured a $10 \%$ of leftovers at the end of each meal. The control diet, without cactus, was formulated to provide an average gain of $250 \mathrm{~g}$ /day, according to NRC recommendations (1985).

Ingredients were analyzed for dry matter contents (DM), raw protein (RP), neutral detergent fiber (NDF), acid detergent fiber (ADF), ether extract (EE), calcium and phosphorus, according to the methodologies described by Silva \& Queiroz (2002).

During the 80 days in feedlot, animals were weighed every 14 days and when they reached an average live weight of $35 \mathrm{~kg}$, they were slaughtered after a 24-hour fasting of solid food and 16-hour fasting of liquid food, to obtain live weight at slaughter. Slaughter was performed at EMEPA's slaughterhouse by electrical stunning, followed by incision on the external jugular vein. Blood was collected and weighed. During the skinning, the skin was weighed, and when the viscera were removed, gastrointestinal tract was weighed full and empty, as well as bladder and gall bladder, for obtaining empty body weight (EBW), by subtracting the weights of gastrointestinal, gall bladder and bladder contents from the slaughter weight (SW). Liver, respiratory tract, reproductive tract, heart and kidneys were also weighed. Subsequently, after detachment of the head and anterior and posterior paws, paws were weighed. The yield of non-carcass components (skin, blood, paws, gastrointestinal tract, liver, respiratory tract, reproductive tract, heart and kidneys) was related to the empty body weight. Then, carcasses were weighed to obtain hot carcass weight (HCW), and cooled in cold chamber at $5{ }^{\circ} \mathrm{C}$, stored in plastic bags, where they were kept for 24 hours. At the end of this period, carcasses were weighed to obtain cold carcass weight (CCW).

Hot carcass weight (HCC) was used to estimate the yield of hot carcass or actual yield $[\mathrm{RY}=(\mathrm{HCW} / \mathrm{SW}) \times 100]$ and biological yield $[\mathrm{BY}=(\mathrm{HCW} / \mathrm{EBW}) \times 100]$. The components of the animal body not included in the carcass weight were called "non-carcass components" (NCC), which resulted from the subtraction of the hot carcass weight from the weight of non-carcass components (NCC) = (EBW-HCW). The yield of the NCC (NCCY) in relation to the empty body weight (EBW) was also determined. Based on the yield of non-carcass components, the yield of non-carcass edible components (blood, head, paws,

Table 1 - Diet composition

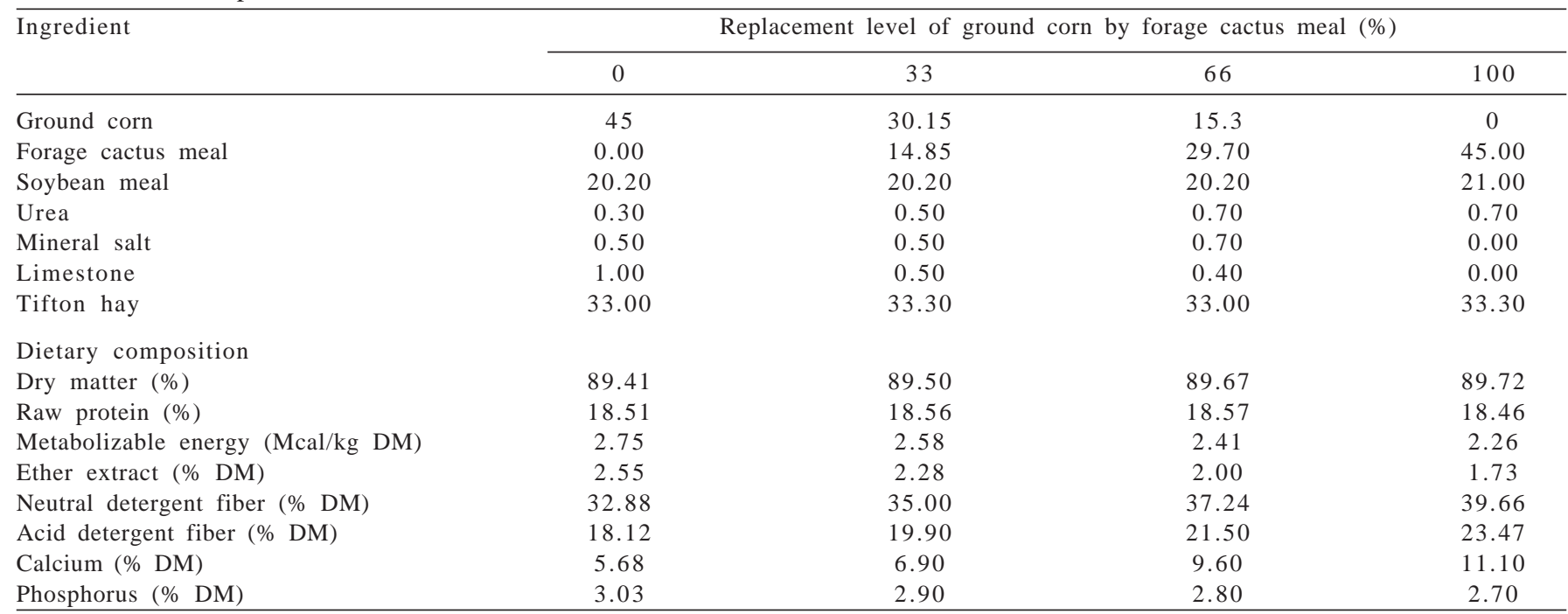


gastrointestinal tract, liver, respiratory tract, reproductive tract, heart and kidneys) was determined in relation to EBW.

Cold carcass weight (CCW) was used to estimate the yield of the cold/commercial carcass [CY $=(C C W / S W) \times 100]$ and the loss of weight caused by the cooling process $[\mathrm{CP}=(\mathrm{HCW}-\mathrm{CCW} / \mathrm{HCW}) \times 100]$.

After cooling, carcasses were divided into two halfcarcasses. The left half-carcasses were separated in prime cuts (leg and loin), choice cuts (shoulder and ribs) and good cuts (neck). These meat cuts were weighed and their yields were determined in relation to the cold carcass weight, also by category. Also, the weighted value of each meat cut and of each category in relation to the weight calculated from the weighting factors $0.4 ; 0.7$ and 1 , respectively, for cuts considered as good, choice and prime cuts were weighted, according to Cezar \& Sousa (2007).

The design was completely randomized, with four treatments and ten replicates. Data were submitted to variance and regression analyses at a $5 \%$ level of probability. Statistical data processing was done using the SAS (1999) software.

\section{Results and Discussion}

There was no influence $(\mathrm{P}>0.05)$ of the levels of replacement of ground corn by forage cactus meal on weight and yield of non-carcass components (NCC), loss by cooling or yield of edible viscera (YEV), with averages of $13.03 \mathrm{~kg}$; $42.42 \%$; 2.41 and $28.43 \%$ (Table 2). Interestingly, non-carcass components represented nearly $50 \%$ compared with the EBW, which is consistent with Carvalho et al. (2005), who affirmed that non-carcass components might account for more than $50 \%$ of the live weight of the animals, and this percentage is influenced by factors such as diet and other parameters responsible for the variation in the live weight of animals. Also, $28.43 \%$ of edible non-carcass components were obtained, which is very similar to the $26.94 \%$ obtained by Medeiros et al. (2008), who assessed the effects of concentrate levels on non-carcass components of Morada Nova ovines in feedlot.

Weight at slaughter, empty body weight, hot carcass weight and cold carcass weight decreased linearly with the increase in the levels of replacement of ground corn by forage cactus. The increase of $1.0 \%$ in the level of replacement made it possible to estimate a decrease of 20;30; 20 and $20 \mathrm{~g}$ in the weights, respectively, which is possibly related to a decrease in fat deposition in the body, which, according to Kosloski (2002) is caused by the lower concentration of propionic acid and circulating energy, due to the low content of soluble carbohydrates of the forage cactus (Menezes et al., 2005) and the decrease in the content of metabolizable energy inherent to the level of replacement $(2.26 \mathrm{Mcal} / \mathrm{kg}$ ) compared with the diet with $0 \%$ of forage cactus meal ( $2.75 \mathrm{Mcal} / \mathrm{kg})$. There was no difference in loss by cooling, which is considered adequate, between 3.0 and 4.0\%, according to Almeida Junior et al. (2004).

It is important to stress the high coefficient for loss by cooling (52.96\%), which can be considered normal, once this variable is intrinsically unstable. Xenofonte et al. (2009) conducted an experiment with SPRD ovines $(1 / 2$ Dorper $\times 1 / 2$ Santa Inês) in feedlot fed on babassu meal and obtained an average value of $4.74 \%$, with a coefficient of variation of $78.70 \%$ for loss by cooling, and affirmed that this high coefficient of variation was due to the speed of the air in the cold chamber.

Table 2 - Absolute (kg) and relative (\%) measurements of the characteristics of the carcass and of non-carcass components of Santa Inês ovines fed on diets of forage cactus meal in replacement of ground corn

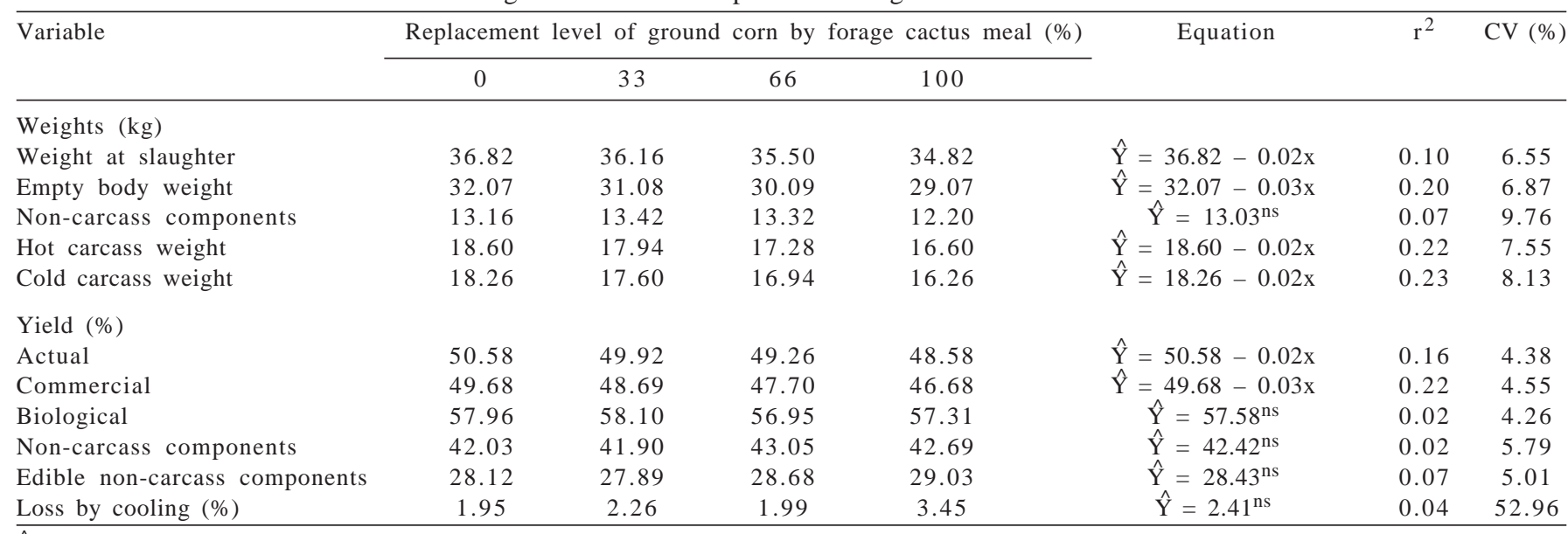

$\hat{Y}=$ dependent variable; $\mathrm{X}=$ level of supplementation; ${ }^{\mathrm{ns}}=$ not significant at a $5 \%$ probability level. 
The actual yield and the commercial yield of the carcass decreased linearly with the increased level of replacement of ground corn by forage cactus meal; whereas the biological yield (BY) was not influenced by the levels of replacement. The biological yield is the variable that best represents the carcass components, since it does not consider the abiotic content (Cezar \& Sousa, 2007). Thus, the variation in the findings obtained for the actual and commercial yields might have been influenced by the contents of gastrointestinal tract, gall bladder and bladder. A similar situation was found by Xenofonte et al. (2009) in a study with babassu meal, where an average on 56.07\% was obtained for the biological yield.

Yields of the leg and loin, from prime cuts (Y1R) in relation to the carcass were not influenced $(\mathrm{P}>0.05)$ by the diet of the animals (Table 3). According to Cezar \& Sousa (2007), more important than the yield of commercial meat cuts is the relative value of each meat cut or category in relation to the weighted value, that is, how much each meat cut/category has commercially yielded in relative terms. Given the importance of the commercial value of these meat cuts, Cezar \& Sousa (2007) proposed weighting factors between the three categories of commercial meat cuts, where factor 1 is for prime cuts, 0.7 for choice cuts and 0.4 for good cuts. Thus, the higher the weight of the prime cuts and the lower the weight of good cuts, the higher the commercial value of the carcass. In the regional composition, maximum commercial yield of prime cuts is sought (Rodrigues et al., 2008). In the present experiment, this value was, on average, above $50 \%$, confirming the biological variability of the use of forage cactus meal as an alternative to ground corn.
Shoulder yield had positive linear behavior, whereas that of the ribs was negative, with increase in the levels of replacement of ground corn by forage cactus meal. Thus, for every $1.0 \%$ increase in the forage cactus diet (fed to the animals in replacement of the ground corn diet), a $0.01 \%$ increase and a $0.02 \%$ decrease were observed, respectively. Although the yields of shoulder and ribs were influenced by the diet fed to the animals, these yields were not influenced by the replacement of ground corn by forage cactus meal ( $P>0.05$ ), with an average of $48.40 \%$, when they were assessed together with the yields of the choice cuts (Y2R). The behavior observed in the yields of shoulder and ribs in relation to the carcass was the same observed for the weighted value of these cuts, with the same increase and decrease ratios, respectively. The average for the weighted values of the choice cuts was influenced by the growing levels of replacement and was lower, $41.80 \%$, which has to be mentioned, since commercial profitability is the most important characteristic in a prime cut.

Yield (Y3R) and weighted value of the neck had a positive linear behavior, with $0.01 \%$ and $0.005 \%$ ratios, respectively, in relation to the increase in the level of replacement of ground corn by forage cactus meal. Since the neck is a good cut, increase in its yield is not desired. Although the good cut was positively influenced by the levels of replacement of ground corn by forage cactus meal, there was no change in the yield and weighted value of prime cuts, which demonstrates the potential of forage cactus meal as an alternative diet to ground corn.

In the process performed to obtain the carcass, noncarcass components called "fifth quarter" are originated,

Table 3 - Yield of commercial meat cuts and categories and weighted value of the commercial meat cuts and categories of Santa Inês ovines fed on diets containing forage cactus meal in replacement of ground corn

\begin{tabular}{|c|c|c|c|c|c|c|c|}
\hline \multirow[t]{2}{*}{ Variable } & \multicolumn{4}{|c|}{ Level of replacement (\%) } & \multirow[t]{2}{*}{ Equation } & \multirow[t]{2}{*}{$\mathrm{r}^{2}$} & \multirow[t]{2}{*}{ CV (\% } \\
\hline & 0 & 33 & 66 & 100 & & & \\
\hline \multicolumn{8}{|l|}{ Yields (\%) } \\
\hline Leg & 30.00 & 29.89 & 30.70 & 30.47 & $\hat{Y}=30.26^{\mathrm{ns}}$ & 0.05 & 3.79 \\
\hline Loin & 14.03 & 14.28 & 14.05 & 13.43 & $\hat{Y}=13.95^{\mathrm{ns}}$ & 0,05 & 7.33 \\
\hline Prime cuts (Y1R) & 44.03 & 44.17 & 44.76 & 43.90 & $\hat{Y}=44.21^{\mathrm{ns}}$ & 0.01 & 2.62 \\
\hline Shoulder & 17.55 & 17.88 & 18.21 & 18.55 & $\hat{Y}=17.55+0.01 x$ & 0.16 & 5.87 \\
\hline Ribs & 31.35 & 30.69 & 30.03 & 29.35 & $\hat{Y}=31.35-0.02 x$ & 0.21 & 5.48 \\
\hline Choice cuts (Y2R) & 48.90 & 48.57 & 48.24 & 47.90 & $\hat{\mathrm{Y}}=48.40^{\mathrm{ns}}$ & 0.08 & 2.79 \\
\hline Neck (Y3R) & 6.90 & 7.23 & 7.56 & 7.90 & $\hat{Y}=6.90+0.01 x$ & 0.10 & 14.69 \\
\hline \multicolumn{8}{|l|}{ Weighted value (\%) } \\
\hline Leg & 37.00 & 36.84 & 37.75 & 37.76 & $\hat{Y}=37.34^{\mathrm{ns}}$ & 0.07 & 3.55 \\
\hline Loin & 17.31 & 17.60 & 17.28 & 16.63 & $\hat{Y}=17.20^{\mathrm{ns}}$ & 0.05 & 7.07 \\
\hline Prime cuts & 54.31 & 54.45 & 55.03 & 54.40 & $\hat{\mathrm{Y}}=54.54 \mathrm{~ns}$ & 0.01 & 2.12 \\
\hline Shoulder & 15.14 & 15.47 & 15.80 & 16.14 & $\hat{Y}=15.14+0.01 x$ & 0.17 & 5.98 \\
\hline Ribs & 27.04 & 26.38 & 25.72 & 25.04 & $\hat{Y}=27.04-0.02 x$ & 0.19 & 5.51 \\
\hline Choice cuts & 42.18 & 41.85 & 41.52 & 41.18 & $\hat{\mathrm{Y}}=41.80 \mathrm{~ns}$ & 0.05 & 2.91 \\
\hline Neck & 3.40 & 3.57 & 3.73 & 3.90 & $\hat{Y}=3.40+0.005 x$ & 0.10 & 15.35 \\
\hline
\end{tabular}

$\hat{Y}=$ dependent variable; $\mathrm{X}=$ level of supplementation; ${ }^{\text {ns }}=$ not significant at a $5 \%$ probability level. 
which, according to Santos et al. (2005), are important because they improve the cost-benefit relation in the meat production process. Also, according to Joy et al. (2008), they affect carcass yield. According to reports of Delfa et al. (1991), the value obtained with non-carcass components may cover part of the expenses incurred in the slaughter process, and, consequently, generate profit. The viscera can be used for human consumption, since they are an important source of animal protein, with a nutritional value compatible with the carcass (Yamamoto et al., 2004). Pereira Filho et al. (2008) affirmed that the yield of these viscera and organs, in relation to the empty body weight, should be studied to avoid the influence from the gastrointestinal content.

The yields of non-carcass components in relation to empty body weight were not influenced by the levels of replacement of ground corn by forage cactus meal, except for the yield of the head, which grew linearly (Table 4). According to Berchielli (2006), the development of the digestive tract is associated to the type and quality of the ingested food, indicating that the replacement of ground corn by forage cactus meal did not interfere with the gastrointestinal filling to the point of causing differences in the yield of the digestive tract, and, thus, the levels of forage cactus used had similar yields $(\mathrm{P}>0.05)$, although the forage cactus had a lower content of soluble carbohydrates (Menezes et al., 2005) and the content of metabolizable energy decreased as the share of cactus in the diet increased. Rosa et al. (2002) affirmed that the gastrointestinal tract has late heterogonic growth, i.e., the longer the termination period of lambs, the more developed it shall be. Thus, since the feedlot period did not differ between the levels of replacement of ground corn by forage cactus meal, there was no variation in the gastrointestinal yields.

According to Louvandini et al. (2007), the chemical composition of the diet may influence the growth speed of organs and viscera, especially in relation to the energy content, which did not occur in the present experiment where organs and viscera had a similar yield, even with energy contents varying from 2.75 to $2.26 \mathrm{Mcal} / \mathrm{kg}$, due to the inclusion of a diet with forage cactus meal.

Yield of kidneys and liver, organs that actively participate in the metabolism of nutrients and respond to the intake of different energy levels of the diet (Owens et al., 1993), was not influenced ( $P>0.05$ ) by the levels of replacement of ground corn by forage cactus meal, suggesting that the level of metabolism in the referred organs remained unchanged with a diet of forage cactus meal.

Yield of the respiratory tract and heart was not influenced by the levels of replacement of diet, as expected, because the heart and the lungs play an essential role in the supply of nutrients, regardless of the type of diet (Ferreira et al., 2000).

The level of replacement of ground corn by forage cactus meal had no effect $(\mathrm{P}>0.05)$ on the yields of paws and skin. The lack of impact of the replacement diet on the yield of paws was expected because their development occurs in the early growth period. The skin is formed in the intermediate growth period, because it is concomitant to the body development (Rosa et al., 2002). Even though the empty body weight has been influenced by the increased level of forage cactus in the diet, this has not changed the skin yield. The yields of organs and viscera were similar, probably because the animals belonged to the same genetic group and had equal age and empty body weight, although they were fed different diets. This finding corroborates the assertion of Fimbres et al. (2001) that organ development is related to the size of the animal. Therefore, even a higher level of replacement of ground corn by forage cactus meal enabled a provision of nutrients capable of ensuring the yield of viscera and organs in relation to the normal empty body weight.

Table 4 - Yield of non-carcass components in relation to the empty body weight of Santa Inês ovines fed on diets containing forage cactus meal in replacement of ground corn

\begin{tabular}{|c|c|c|c|c|c|c|c|}
\hline \multirow[t]{2}{*}{ Variable } & \multicolumn{4}{|c|}{ Level of replacement (\%) } & \multirow[t]{2}{*}{ Equation } & \multirow[t]{2}{*}{$\mathrm{r}^{2}$} & \multirow[t]{2}{*}{ CV $(\%$} \\
\hline & 0 & 33 & 66 & 100 & & & \\
\hline Digestive tract (\%) & 9.80 & 10.40 & 10.40 & 10.41 & $\hat{Y}=10.26^{\mathrm{ns}}$ & 0.04 & 9.16 \\
\hline Reproductive tract (\%) & 1.60 & 1.66 & 1.69 & 1.57 & $\hat{Y}=1.63^{\mathrm{ns}}$ & 0.01 & 20.10 \\
\hline Respiratory tract (\%) & 1.97 & 1.82 & 2.07 & 2.08 & $\hat{Y}=1.98^{n s}$ & 0.07 & 12.45 \\
\hline Kidneys (\%) & 0.35 & 0.33 & 0.35 & 0.37 & $\hat{Y}=0.35^{n s}$ & 0.07 & 10.71 \\
\hline Liver (\%) & 1.86 & 1.93 & 1.92 & 1.84 & $\hat{Y}=1.89^{n s}$ & 0.01 & 9.73 \\
\hline Heart (\%) & 0.77 & 0.77 & 0.74 & 0.69 & $\hat{\mathrm{Y}}=0.74^{\mathrm{ns}}$ & 0.06 & 15.85 \\
\hline Blood (\%) & 4.13 & 3.56 & 3.85 & 3.88 & $\hat{\mathrm{Y}}=3.85^{\mathrm{ns}}$ & 0.01 & 11.49 \\
\hline Paws (\%) & 2.54 & 2.45 & 2.52 & 2.70 & $\hat{Y}=2.55^{\mathrm{ns}}$ & 0.09 & 8.11 \\
\hline Head (\%) & 4.95 & 5.08 & 5.21 & 5.35 & $\hat{\mathrm{Y}}=4.95+0.004 \mathrm{x}$ & 0.21 & 5.82 \\
\hline Skin (\%) & 10.31 & 10.26 & 10.28 & 10.44 & $\hat{Y}=10.32^{n s}$ & 0.01 & 9.46 \\
\hline
\end{tabular}

$\hat{\mathrm{Y}}=$ dependent variable; $\mathrm{x}=$ level of supplementation; ${ }^{\mathrm{ns}}=$ not significant at a $5 \%$ probability level. 
Yield of the head showed linear increase, so that an increase of $1.0 \%$ in the level of replacement of ground corn by forage cactus meal promoted an increase of $0.004 \%$ in the yield of the head. The head develops early, and its proportion in relation to the live weight decreases with animal development (Roque et al., 1999). Thus, the increased yield of head was a result of the linear decrease of the empty body weight.

\section{Conclusions}

Replacing ground corn with forage cactus meal in the diet fed to Santa Inês ovines in feedlot does not affect biological yield, yield and weighted value of prime and choice cuts, or the yield of viscera and organs. The forage cactus meal has a biological efficiency similar to that of ground corn.

\section{References}

ALMEIDA JUNIOR, G.A.; COSTA, C.; MONTEIRO, A.L.G. et al. Desempenho, características da carcaça e resultado econômico de cordeiros criados em Creep Feeding com silagem de grãos úmidos de milho. Revista Brasileira de Zootecnia, v.33, n.4, p.1048-1059, 2004.

ALVES, K.S.; CARVALHO, F.F.R.; FERREIRA, M.A. et al. Níveis de energia em dietas para ovinos santa inês: características de carcaça e constituintes corporais. Revista Brasileira de Zootecnia, v.32, n.6, p.1927-1936, 2003.

BATISTA, A.M.V.; MUSTAFA, A.F.; SANTOs, G.R.A. et al. Chemical composition and ruminal dry matter and crude protein degradability of spineless cactus. Journal Agronomy and Crop Science, v.189, n.2, p.123-126, 2003.

BEN SALEM, H.; ABDOULI, H.; NEFZAOUI, A. et al. Nutritive value, behaviour and growth of Babarine lambs fed on oldman saltbush (Atriplex nummularia, L.) and supplemented or not with barley grains or spineless cactus (Opuntia ficus indica, var. inermis) pads. Small Ruminant Research, v.59, p.229-237, 2005.

BEN SALEM, H.; NEFZAOUI, A.; ABDOULI, H. et al. Effect of increasing level spineless cactus (Opuntia ficus-indica var.inermes) on intake and digetion by sheep given straw-based diets. Journal of Animal Science, v.62, n.1, p.293-299, 1996.

BERCHIELLI, T.T.; PIRES, A.V.; OLIVEIRA, S.G. Nutrição de ruminantes. Jaboticabal: FUNEP, 2006. 583p.

BISPO, S.V.; FERREIRA, M.A.; VERAS, A.S.C. et al. Palma forrageira em substituição ao feno de capim-elefante. Efeito sobre consumo, digestibilidade e características de fermentação ruminal em ovinos. Revista Brasileira de Zootecnia, v.36, n.6, p.1902-1909, 2007.

CARVALHO, S.; VERGUEIRO, A.; KIELING, R. Avaliação da suplementação concentrada em pastagem de Tifton-85 sobre os componentes não carcaça de cordeiros. Ciência Rural, v.15, n.2, p.435-439, 2005.

CEZAR, M.F.; SOUSA, W.H. Carcaças ovinas e caprinas: obtenção, avaliação, classificação. Uberaba: Agropecuária Tropical, 2007. 147p.

COELHO DA SILVA, J.F.; LEÃO, M.I. Fundamentos da nutrição de ruminantes. Piracicaba: Livroceres, 1979. 380p.

DELFA, R.; GONZALEZ, C.; TEIXEIRA, A. El quinto quarto. Revista Ovis, v.17, p.49-66, 1991

FERREIRA, M.A.; VALADARES FILHO, S.C.; MUNIZ, E.B. et al. Características das carcaças, biometria do trato gastrintestinal, tamanho dos órgãos internos e conteúdo gastrintestinal de bovinos F1 Simental x Nelore alimentados com dietas contendo vários níveis de concentrado. Revista Brasileira de Zootecnia, v.29, n.4, p.1174-1182, 2000.

FIMBRES, H.; HERNANDEZ-VIDALA, G.; PICON-RUBIOA, J.F. et al. Productive performance and carcass characteristics of lambs fed finishing ratio containing various forage levels. Small Ruminant Research, v.43, n.3, p.283-288, 2001.

JOY, M.; RIPOLL, G.; DELFA, R. Effects on feeding system on carcass and non-carcass composition of Churra Tensina light lambs. Small Ruminant Research, v.78, p.123-133, 2008.

KOSLOSKI, G.V. Bioquímica dos ruminantes. Santa Maria: Universidade Federal de Santa Maria, 2002. 140p.

LOPES, E.B. Palma forrageira: cultivo, uso atual e perspectivas de utilização no semi-árido Nordestino. João Pessoa: EMEPA/ FAEPA, 2007.130p.

LOUVANDINI, H.; NUNES, G.A.; GARCIA, J.A.S. et al. Desempenho, características da carcaça e constituintes corporais de ovinos Santa Inês alimentados com farelo de girassol em substituição ao farelo de soja na dieta. Revista Brasileira de Zootecnia, v.36, n.3, p.603-609, 2007.

MEDEIROS, G.R.; CARVALHO, F.F.R.; FERREIRA, F.A. et al. Efeito dos níveis de concentrado sobre os componentes nãocarcaça de ovinos Morada Nova em confinamento. Revista Brasileira de Zootecnia, v.37, n.6, p.1063-1071, 2008.

MELO, A.A.S. FERREIRA, M.A.; VÉRAS, A.S.C. et al. Substituição parcial do farelo de soja por uréia e palma forrageira (Opuntia ficus-indica Mill) em dietas para vacas em lactação Desempenho. Revista Brasileira de Zootecnia, v.32, n.3, p.727-736, 2003.

MENEZES, R.S.C.; SIMOES, D.A.; SAMPAIO, E.V.S.B. A palma no Nordeste do Brasil: conhecimento atual e novas perspectivas de uso. Recife: Editora Universitária da UFPE, 2005. 258p.

MULLER, D.M.; SHOOP, M.C.; LAYCOCK, W.A. Mechanical harvesting of plains prickly pear for control feeding. Journal Range Manage, v.47, p.251-254, 1994.

NATIONAL RESEARCH COUNCIL - NRC. Nutrient requirements of sheep. 6.ed. Washington, D.C.: National Academy of Science, 1985. 99p.

OWENS, F.N.; DUBESKI, P.; HANSON, C.F. Factors that al the growth and development of ruminants. Journal of Animal Science, v.71, p.3152-3172, 1993.

PEREIRA FILHO, J.M.; RESENDE, K.T.; TEIXEIRA, I.A.M.A. et al. Características da carcaça e alometria dos tecidos de cabritos F1 Boer $\times$ Saanen. Revista Brasileira de Zootecnia, v.37, n.5, p.905-912, 2008.

RODRIGUES, G.H.; SUSIN, I.; PIRES, A.V. et al. Polpa cítrica em rações para cordeiros em confinamento: características da carcaça e qualidade da carne. Revista Brasileira de Zootecnia, v.37, n.10, p.1869-1875, 2008

ROQUE, A.P.; OSÓRIO, J.C.S.; JARDIM, P. et al. Produção de carne em ovinos de cinco genótipos. 6. Desenvolvimento relativo. Ciência Rural, v.29, n.3, p.549-553, 1999.

ROSA, G.T.; PIRES, C.C.; SILVA, J.H.S. et al. Proporções e coeficientes de crescimento dos não-componentes da carcaça de cordeiros e cordeiras em diferentes métodos de alimentação. Revista Brasileira de Zootecnia, v.31, n.6, p.2290-2298, 2002.

SANTOS, N.M.; COSTA, R.G.; MEDEIROS, A.N. et al. Caracterização dos componentes comestíveis não constituites da carcaça de caprinos e ovinos. Agropecuária Técnica, v.26, n.2, p.77-85, 2005.

SILVA, D.J.; QUEIROZ, A.C. Análise de alimentos: métodos químicos e biológicos. 3.ed. Viçosa, MG: Universidade Federal de Viçosa, 2002. 235p.

STATISTICAL ANALYSES SYSTEM - SAS. User's guide. Cary: Sas Institute Inc., 1999. (CD-ROM).

VAN SOEST, P.J. Nutritional ecology of the ruminant. 2.ed Ithaca: Cornell University Press, 1994. 476p. 
VERAS, R.M.L.; FERREIRA, M.A.; CAVALCANTI, C.V.A. et al. Substituição do milho moído (Zea mays L.) por farelo de palma forrageira (Opuntia ficus-indica Mill cv. Gigante na dieta de ovinos em crescimento. Revista Brasileira de Zootecnia, v.34, n.1, p.351-356, 2005.

XENOFONTE, A.R.B.; CARVALHO, F.F.R.; BATISTA, A.M.V. et al. Características da carcaça de ovinos em crescimento alimentados com rações contendo farelo de babaçu. Revista Brasileira de Zootecnia, v.38, n.2, p.392-398, 2009.
WANDERLEY, W.L.; FERREIRA, M.A.; ANDRADE, D.K.B. et al. Palma forrageira (Opuntia fícus-indica Mill) em substituição de sorgo (Sorghum bicolor (L.) Moench) na alimentação de vacas em lactação. Revista Brasileira de Zootecnia, v.31, n.1, p.273-281, 2002.

YAMAMOTO, S.M.; MACEDO, F.A.; MEXIA, A.A. et al. Rendimento dos cortes e não componentes das carcaças de cordeiros terminados com dietas contendo diferentes fontes de óleo vegetal. Ciência Rural, v.34, n.6, p.1909-1913, 2004. 